\title{
Gayo coffee processing with natural, semi- washed and full-washed methods
}

\author{
Hotnida Sinaga ${ }^{1 *}$, Mimi Nurminah ${ }^{1}$, and Adrian Hilman ${ }^{1}$ \\ ${ }^{1}$ Department of Food Science and Technology, Faculty of Agriculture, Universitas Sumatera Utara, \\ 20155, Medan, Indonesia.
}

\begin{abstract}
Gayo area is the largest Arabica coffee production in Asia. The materials used in this research were coffee beans which are natural, semiwashed, and fully-washed processed coffee. This study aimed to determine the physicochemical of green bean will the various processing. The moisture content of three green bean coffee were $9.78 \%, 9.60 \%$ and $11.03 \%$ for natural, semi-washed and full-washed processing, respectively. The ash content ranged from $3.19 \%$ for natural processing to $4.33 \%$ for full-washed processing. Full washed green bean coffee had the highest lipid content, $12.5 \pm 0.20 \%$ compared to the other coffee. Moreover, the lowest $\mathrm{pH}$ and specific volume were found in natural processing coffee, 5.63 and $1.66 \mathrm{~mL} / \mathrm{g}$, respectively. The finding result shows that coffee characteristics depending on the processing methods. Future work will be done by applying various packaging for the coffee bean.
\end{abstract}

\section{Introduction}

Coffee has popular among people in various countries and has a high selling value and export value. Indonesia is the number 4 coffee producer after Brazil, Vietnam, and Colombia. The largest Arabica coffee production centre for the Indonesia, province is in the Central Aceh Regency [1]. Coffee plants in Central Aceh Regency were 81,000 ha, which meant that there was always an increase in planting area which directly increased coffee production in Central Aceh District [2]. Bandingkan dengan berapa luas lahan kopi di Indonesia.

Gayo Arabica coffee has characteristics and quality that can still be maintained. Occurs due to biophysical factors, such as soil conditions, climate and altitude, which are planted at an altitude of 1,000-1,400 m ASL. Cultural factors of the people who still use simple methods in the processing and roasting methods. Coffee production in Indonesia is very large, specialty coffee production from Aceh Province. In 2017 the average production of arabica coffee in Aceh province reached 189.74 thousand tons and was the first rank coffee in Indonesia from 2015 to 2019 which reached 55,885 tons average of production per year. Specialty coffee is coffee that grows in a special micro-geographic climate resulting in a distinctive and unique taste that is well-known among the international community [3]. Specialty coffee also tends to be stated as high quality and unique coffee because of its special processing such as semi washed, fully washed, and natural.

\footnotetext{
* Corresponding author : hotnida@usu.ac.id
} 
Coffee processing can be done in many ways, one of which is the fermentation process. The main purpose of the fermentation process is to release the mucilage (mucilage layer) attached to the coffee beans. The activity of the metabolism of microorganisms results in the decomposition of the mucilage which is rich in sugar and pectin which become nutrients during the fermentation process. One type of microorganism that is able to ferment or remodel sugar is Saccharomyces cereviceae [4].

There are several ways to process coffee, namely dry (natural), wet (full-washed) and semi-wet (semi-washed) methods. The difference between the three processes is the use of water required for each process for fruit peeling and for washing coffee cherries. Of the three processes, there is one processing that has the most influence on the quality of coffee, namely the wet processing which requires a fermentation process for the final result. Fermentation is done to form a lighter after taste on the coffee taste and to remove the mucus layer that is still attached to the coffee which makes the taste bitter. The application of this process must be done carefully because it can cause damage to the taste. Flavor spoilage is an undesirable end result for coffee lovers [5].

The process of full-washed is a processed coffee by fermentation. The time required in the fully washed process is about 7 days. The fully-washed coffee has a lighter and softer taste. And semi-washed processed is a way of processing that is done by removing the outer shell of the coffee cherries and then dried until clean from the coffee mucilage and then washed in a semi-wet process. The natural processed is done by sorting coffee cherries that have good quality, then dried in the sun until the moisture content reached $12 \%$. After that, the dried coffee cherries will be processed into a hulling machine [6].

Fermentation is done to remove the mucus attached to the coffee beans and improve the taste of the coffee. After fermentation, the coffee beans are washed until the coffee beans are clean, then the coffee beans are dried in the sun to dry with a moisture content of $<12 \%$. The horn skin on the coffee beans is peeled using a huller machine to make green beans [7]. The purpose of this study was to determine the differences in the physicochemical characteristics of the three types of processing, namely semi washed, fully washed and natural processed.

\section{Material and methods}

Materials used in this research were green bean Gayo Arabica coffee that processed by three coffee processing. Which are natural, semi-washed and fully-washed processed coffee

\subsection{Research methods}

\subsubsection{Moisture content}

Determination of water content is based on AOAC (Official Methods of Analysis) (2005) [6]. The analysis was carried out using the gravimetric method, in which an empty cup was heated in an oven at a temperature of $105^{\circ} \mathrm{C}$ for 30 minutes, cooled in a desiccator for 15 minutes, and then weighed. Then a sample of $2 \mathrm{~g}$ was put in a cup whose weight was known, weighed, then dried in an oven at $105^{\circ} \mathrm{C}$ for 3 hours, cooled in a desiccator for 15 minutes, then the cup and its contents were weighed and dried again for 1 hour and cooled in a desiccator. Weighed again to determine the weight then the water content was calculated. Water content is calculated by:.

$$
\text { Water content }(\%)=\frac{\text { Loss of weight }}{\text { Sample weight }} \times 100 \% \text {. }
$$




\subsubsection{Ash content}

Ash content testing was carried out using the Sudarmadji method (1997) [7]. The ash content test was carried out by counting the samples that had been dried to a constant weight and then weighed as much as $5 \mathrm{~g}$. The sample was put into a porcelain dish with known initial weight and burned for 1 hour in the furnace at $100{ }^{\circ} \mathrm{C}, 2$ hours at $300{ }^{\circ} \mathrm{C}$, and then 2 hours at $500{ }^{\circ} \mathrm{C}$. The porcelain dish was cooled and then removed from the furnace and put in a desiccator for 15 minutes and then Weighed again to determine the weight then the ash content was calculated. Ash content is calculated by:

Ash Content $(\%)=\frac{\text { Ash Weight }}{\text { Sample weight }} \times 100 \%$

\subsubsection{Lipid content}

The lipid content test was carried out based on the AOAC method (2005). Lipid analysis was carried out using the Soxhlet method. A sample of $5 \mathrm{~g}$ was wrapped in filter paper, then placed in a Soxhlet extraction apparatus. The hexane lipid solvent is put into the lipid flask, then reflux is carried out for \pm 6 hours until the solvent drops back into the lipid flask and is clear in color. The solvent in the lipid flask is distilled and collected again. Then the lipid flask containing the extracted lipid was heated in an oven at $70^{\circ} \mathrm{C}$ until it reached a constant weight, then cooled in a desiccator. The volumetric flask and weighed again to find out the weight then the fat content was calculated.

$$
\text { Lipid content }(\%)=\frac{\text { Lipid Weight }}{\text { Sample weight }} \times 100 \%
$$

\subsubsection{Acidity level}

The acidity test was carried out based on the AOAC (2005). The degree of acidity of coffee was measured using a $\mathrm{pH}$ meter and calibrated with a buffer solution with $\mathrm{pH}$ values of 4 and 7. The sample was prepared as much as $1 \mathrm{ml}$, then added $10 \mathrm{ml}$ of distilled water, after that the sample was stirred for 5 minutes, the sample was transferred to a measuring cup, $\mathrm{pH}$ - meter is immersed in the sample approximately $2-4 \mathrm{~cm}$. The $\mathrm{pH}$ value is obtained by reading the scale indicated by the pointer needle.:

\subsubsection{Specific volume}

The measurement of the volume of coffee using the displacement test method is by Yananta (2003) [8]. Put the sesame seeds into a graduated cylinder whose volume is known and then the weight of the sesame seeds is weighed from the graduated cylinder. Then, the graduated cylinder is filled again with half of the sesame. Put one of green bean into the container, and the container is filled with the remaining sesame seeds. Sesame seeds that don't go into the container are weighed as spilled sesame seeds. Specific volume is calculated by:

$$
\text { Specifik volume }(m l)=\frac{\text { Spilled sesame weight }(\mathrm{g})}{\text { Whole weight of sesame }(\mathrm{g})} \times \text { Volume graduated cylinder. }
$$

\subsection{Data analysis}

This data analysis used non-factorial completely randomized design with 3 replications comparing coffee from natural, semi-washed and full-washed coffee processing. Parameters analyzed were moisture content, ash content, lipid content, $\mathrm{pH}$, and the specific volume. 


\section{Result and discussion}

Psycho-chemical analysis on the sample including moisture, ash, lipid, acidity and specific volume test. Each test was done with 3 repetitions and averaged.

Table 1. Psycho-chemical characteristic of green bean Arabica Gayo coffee

\begin{tabular}{|c|c|c|c|}
\hline \multirow{2}{*}{ Parameter } & \multicolumn{3}{|c|}{ Green Bean of Arabica Gayo Coffee } \\
\cline { 2 - 4 } & Natural & Semi-washed & Full-washed \\
\hline Moisture Content (\%) & $9.78 \pm 0.25^{\mathrm{aA}}$ & $9.60 \pm 0.11^{\mathrm{bB}}$ & $11.03 \pm 0.48^{\mathrm{aA}}$ \\
\hline Ash Content $(\%)$ & $3.19 \pm 0.15^{\mathrm{bB}}$ & $4.16 \pm 0.02^{\mathrm{bB}}$ & $4.33 \pm 0.10^{\mathrm{aA}}$ \\
\hline Lipid Content $(\%)$ & $9.59 \pm 0.86^{\mathrm{bB}}$ & $11.35 \pm 1.54^{\mathrm{aAB}}$ & $12.5 \pm 0.20^{\mathrm{aA}}$ \\
\hline $\mathrm{pH}$ & $5.63 \pm 0.01^{\mathrm{cC}}$ & $6.21 \pm 0.03^{\mathrm{bB}}$ & $6.24 \pm 0.06^{\mathrm{aA}}$ \\
\hline Spesific Volume $(\mathrm{mL} / \mathrm{g})$ & $1.30 \pm 0.28^{\mathrm{bB}}$ & $1.13 \pm 0.01^{\mathrm{bB}}$ & $1.66 \pm 0.06^{\mathrm{aA}}$ \\
\hline
\end{tabular}

\subsection{Moisture contents}

The moisture content in green bean coffee can determine the quality and the taste of brewed coffee [11]. The value of moisture content that has been treated with three types of processing has significant effect with a moisture content ranged from $9.60 \pm 0.11$ to $11.03 \pm 0.48 \%$. The differences between each processed green bean coffee caused by the length of fermentation that affects the moisture content of green bean coffee, in which the moisture content increased with the longer fermentation time [12]. The use of water for fermentation in full-washed processing caused the moisture content of the green beans is higher than that of the other processing methods. Full-washed processed coffee has a longer fermentation time than semi-washed, that caused fully-washed processed coffee has a higher moisture content than the others. Although significant differences were found with the moisture content but the three methods of processing have met SNI (Indonesian National Standard) and ICO (International Coffee Organization) standard. The moisture content in SNI 01-2907:2008 states that the maximum water content is 12.5\%, while The International Coffee Organization states that dried green coffee beans should have a moisture content of 8 to $12.5 \%$ [13].

\subsection{Ash content}

Ash content is important to test on coffee to know the purity rate of coffee [14]. The ash content in the natural processing type has the lowest ash content compared to the other two processes, it has $3.19 \pm 0.15 \%$ ash content. The release of the epidermis in coffee beans occurs more completely in the fermentation process in the form of cherries [15]. Meanwhile, the semi-washed and fully-washed processes have a fermentation method with coffee beans that have been separated from the husks through the hulling method. The high ash content in green beans Arabica Gayo coffee is due to the high mineral content, besides that, dirt and remaining epidermis can also affect the ash content contained in coffee beans. Differences in coffee ash content are caused by several factors, including coffee quality [16]. 


\section{3 . Lipid content}

In terms of quality, lipids on coffee bean have an important role in aroma retention [17]. The lipid content in the three types of processing has no significant effect. Lipid content contained in the three types of processes ranged from $9.59 \pm 0.86$ to $12.5 \pm 0.20 \%$. Lipid content of the three processed Gayo Arabika green beans coffee was still below the standard for Arabica coffee in general. The ICO states that the lipid content in Arabica coffee is around $15 \%$ and can be level up to $17 \%$. The difference in lipid content in each type of coffee processing is due to the different lipid levels in the wax layer around the surface of the coffee green beans [18].

\subsection{Acidity level}

Acidity level of green bean coffee used to determine the quality and flavor of brewed coffee [19]. Based on Table 1, the $\mathrm{pH}$ of green beans Arabica Gayo coffee from natural processed has the lowest $\mathrm{pH}$ value, natural processed with a value of $5.63 \pm 0.01$. When compared to 2 other types of processes that have a $\mathrm{pH}$ above 6.00 , namely $6.21 \pm 0.03$ for the semi-washed processed and $6.24 \pm 0.01$ for the fully-washed processed. This difference in $\mathrm{pH}$ value can be due to differences in the fermentation process in each type of processing [20]. Natural processed coffee has the longest time to fermented due to the fermentation still runs during the drying process with the sun. The $\mathrm{pH}$ value of green bean coffee does not have a significant effect because in the three types of processes because green bean coffee comes from the same area. Location of growth, altitude and cultivation processes and post-harvest processing that affect the $\mathrm{pH}$ level of green coffee beans [21].

\subsection{Specific volume}

The specific volume of coffee needs to be known to see the uniformity of coffee beans. It shows the physical quality of coffee beans for coffee consumers and can be used as a blue print to determine roasting temperature and period [22]. The specific volumes taken from the three types of processes have no significant difference. Where the three types of processing still use the same coffee varieties, namely Arabica coffee from the Gayo highlands. The specific volume differences that occur in each processing process can be caused by the application of different fermentation techniques. Fermentation process in coffee beans caused a breakdown of compounds. Therefore, the breakdown of these compounds causes a decrease in bean weight and volume in coffee beans [23].

\section{Conclusion}

The difference in methods can cause the variety of physicochemical properties of the Gayo green bean coffee. The moisture content and ash content of Gayo Arabica coffee have met the SNI and ICO moisture content standard. However, the lipid content result of the three processed coffee lower than the ICO standard. Full-washed processing resulted in the higher acidity level and the volume specific..

We thank Ministry of Research and Technology/ National Research and Innovation for funding this research with contract number 101/UN5.2.3.1/PPM/KP-DRPM/2021. 


\section{References}

1. I. Zarwinda, D. Sartika, Lantanida Journal, 6 103-107 (2018)

2. Ichsan, Jurnal Ekonimika Indonesia, 5, 16-23 (2016)

3. Y.M. Teniro, Zulfan, Husaini, Jurnal Ilmiah Mahasiswa Pendidikan Sejarah FKIP Unsyiah, 3, 52-63 (2018)

4. J.R. Saragih, Jurnal Wilayah dan Lingkungan, 6, 74-87 (2018)

5. A.R. Sulistyaningtyas Pentingnya pengolahan basah (wet processing) buah kopi robusta (coffea robusta Lindlex.de.Will) untuk menurunkan resiko kecacatan biji hijau saat coffee grading, In Prosiding Seminar Nasional Publikasi Hasil-Hasil Penelitian dan Pengabdian Masyarakat (2017)

6. M. Azizah, R.T.M. Sutamihardja, N. Wijaya, Jurnal Sains Natural Universitas Nusa Bangsa, 9, 37-39 (2019)

7. J. Towaha, Rubiyo, J. Balai Penelitian Tananman Industri dan penyegar, 3, 61-70 (2016)

8. AOAC, Official Methods of Analysis (Washington D.C: The association of Official Analytical Chemists, 2005)

9. S Sumardji, Suhardi, B. Haryono, Prosedur Analisa untuk Bahan Makanan dan Pertanian (Liberty, Yogyakarta, 1997)

10. A.P. Yananta, Perbaikan Proses Tepung Umbi Minor (Skripsi. IPB-Press, Bogor, 2003).

11. Berto Coffee Roaster, Pengaruh kadar air dalam biji kopi terhadap kualitas biji kopi Available from http://berto-online/pengaruh-kadar-air-dalam-biji-kopi-terhadapkualitas/, (2021)

12. W.B.J. Barus, Wahana Inovasi 8, 111-115, (2019)

13. International Coffee Organization, Improving Quality Avalaible from https://www.ico.org/improving_quality.asp, (2017)

14. Coffee and Cocoa Training Center, Jabaran kriteria mutu SNI kopi bubuk Available from https:/www.cctcid.com/2020/12/29/jabaran-kriteria-mutu-sni-kopi-bubuk/, (2021)

15. Z.A. Siregar, R.T.M. Suthamihardja, D Susanty, Jurnal Sains Natural Universitas Nusa Bangsa 10, 87-94, (2020)

16. Wahyuni, S. Rejo, Hasbi, Lama Penyangraian Terhadap Perubahan Karakteristik Biji Kopi dari Berbagai Daerah di Sumatera Selatan (Program Studi Teknik Pertanian UNSRI, Indralaya, 2008)

17. Coffee Chemistry, Lipids in coffee Available from https://www.coffeechemistry.com/lipids-in-coffee, (2017)

18. International Coffee Organization, Why is coffee oily? Available from https://www.ico.org/show_faq.asp?show=33, (2017)

19. N.Z. Rao, M. Fuller M.D. Grim, Foods Journal 9, 1-12, (2020)

20. I.W. Aditya, Kajian Kandungan Kafein Kopi Bubuk, Nilai pH dan Karakteristik Aroma dan Rasa Seduhan Kopi Jantan [Pea Berry Coffee] dan Betina [Flat Beans Coffee] Jenis Arabika dan Robusta Available from https://ojs.unud.ac.id/index.php/ite pa/article/download/22653/14880/, (2020)

21. S. Krishnan, Oxford Research Encyclopedia of Environmental Science 1, 1-34, (2017)

22. O. Sativa, Yuwana, Bonodikun, Jurnal Agroindustri 4, 65-77, (2015) 
23. D. Usman, H. Supriadi, E. Kusdiyantini, Jurnal Biologi 4, 31-40, (2015) 